\title{
DETERMINAN KINERJA PENGELOLAAN KEUANGAN DESA
}

Ade Nur Rabbiah Nasution

Fakultas Ekonomi dan Bisnis Universitas Ahmad Dahlan

Email: adenstn27@gmail.com

\section{Dewi Amalia}

Fakultas Ekonomi dan Bisnis Universitas Ahmad Dahlan

Email: dewi.amalia@act.uad.ac.id

\begin{abstract}
This study aims to examine the factors that determinants of financial management performance in village government. Village financial management is all activities that include planning, implementation, administration, reporting and financial accountability of the village. The Village financial management is carried out based on the principles of governance: transparent, accountable and participatory so that good governance can be implemented in the village government administration system. The object of this research is Panggungharjo Village, Sewon District at Bantul Regency. The variables tested were the capacity of village officials, financial reporting compliance, and quality of supervision of the BPD. The method used in this research is the type of quantitative data which is strengthened by interviews and the samples are the village head, treasurer and BPD in Panggungharjo Village. Data collection in this study was conducted through a survey using a questionnaire technique to 39 respondents and structured interviews with the treasurer and BPD. The results of this study are the capacity of village officials, financial reporting compliance, and the quality of BPD supervision that affect the performance of financial management.
\end{abstract}

Keywords: Village Financial Management Performance, Village Apparatus Capacity, Financial Reporting Compliance, and Quality of BPD Supervision.

\section{LATAR BELAKANG}

Keberadaan desa secara yuridis dalam Undang-Undang Nomor 6 Tahun 2014 tentang desa menjelaskan bahwa desa merupakan kesatuan masyarakat hukum yang memiliki batas wilayah yang mempunyai wewenang untuk mengatur dan mengurus urusan penyelenggaraan pemerintah, pembangunan, dan kepentingan masyarakat setempat berdasarkan prakarsa masyarakat, hak asal usul, dan/atau hak tradisional yang diakui dan dihormati dalam sistem pemerintah Negara Kesatuan Republik Indonesia. Perubahan sistem pemerintah dari sentralisasi pada masa orde baru menjadi desentralisasi membuat perubahan kebijakan yang baru pada kewenangan pemerintah daerah. Sistem desentralisasi yaitu pemerintah pusat memberikan wewenangnya kepada pemerintah daerah untuk menanggulangi pembangunan yang tidak merata dan untuk meningkatkan fungsi-fungsi pelayanan pemerintah kepada masyarakat. Hal tersebut yang menjadikan 
desa menjadi objek yang penting terkait dengan pembangunan di Indonesia. Fokus pembangunan di desa ini dilakukan melalui dana desa.

Dana desa pertama kali digulirkan pada tahun 2015 dengan jumlah anggaran sebesar Rp20,76 triliun. Dana desa merupakan salah satu usaha pemerintah dalam melakukan pemerataan di seluruh wilayah Indonesia yang diwujudkan melalui dana desa yang dialokasikan khusus dalam APBN. Dana desa dihitung berdasarkan jumlah desa dan dialokasikan dengan memerhatikan jumlah penduduk, angka kemiskinan, luas wilayah, dan tingkat kesulitan geografis.

Tujuan dana desa yaitu untuk memperkuat masyarakat desa sebagai subjek dari pembangunan, meningkatkan pelayanan publik di desa, mengentaskan kemiskinan, memajukan perekonomian desa dan mengatasi kesenjangan pembanguan antar desa. Guna mencapai tujuan dana desa tersebut, maka pengelolaan dana desa harus dilakukan berdasar praktik pemerintahan yang baik. Asas pengelolaan dana desa sebagaimana yang terdapat dalam Permendagri Nomor 113 Tahun 2014 yaitu transparan, akuntabel, partisipatif serta dilakukan dengan tertib dan disiplin anggaran.

Permasalahan pengelolaan dana desa yang tidak efisien dan efektif telah menjadi sorotan publik. Kinerja pengelolaan keuangan desa akan menentukan tercapainya atau tidaknya tujuan dana desa. Desa tidah hanya sekedar jadi objek pembangunan tetapi sekarang menjadi subjek untuk membangun kesejahteraan. Widagdo, Widodo, dan Ismail (2016) menyebutkan kondisi perangkat desa yang dianggap masih rendah dan belum kritisnya masyarakat atas pengelolaan anggaran pendapatan dan belanja desa (APBDesa) sehingga bentuk pengawasaan yang dilakukan oleh masyarakat tidak dapat maksimal. Meskipun demikian, terdapat Badan Perwakilan Daerah (BPD) merupakan lembaga yang memiliki garis kordinasi secara struktural dengan pemerintah desa. Munti dan Fahlevi (2017) menemukan bahwa kapasitas aparatur desa, ketaatan pelaporan keuangan, kualitas pengawasan BPD berpengaruh terhadap kinerja pengelolaan keuangan desa.

Peneliti terinspirasi dari penelitian yang dilakukan oleh Munti dan Fahlevi (2017) di Kecamatan Gandapura Kabupaten Bireuen Aceh. Perbedaan penelitian ini dengan penelitian sebelumnya adalah terletak pada metoda penelitian dari sisi teknik penyampelan dan pengumpulan data. Sampel penelitian terdahulu ditetapkan menggunakan sensus, sedangkan penelitian ini menggunakan purposive sampling. Kemudian perbedaan selanjutnya pada teknik pengumpulan data, penelitian sebelumnya menggunakan survei menggunakan kuesioner dan penelitian ini mengkombinasikan dengan teknik wawancara. Penelitian ini bersifat studi kasus dengan mengambil objek penelitian Desa Panggunharjo Kecamatan Sewon Kabupaten Bantul. Desa tersebut menjadi pemenang sebagai salah satu desa terbaik kategori nasional di Indonesia pada tahun 2014 dalam hal pemberdayaan masyarakat, pembangunan desa, inisiatif masyarakat dalam pemerintah, pemahaman aparat dalam sistem informasi penyelenggaraan desa, dan kepatuhan terhadap kebijak pemerintah (http://www.panggungharjo.desa.id/prestasi/). Hal tersebut menjadi motivasi bagi peneliti untuk melakukan penelitian mengenai faktorfaktor yang memengaruhi kinerja pengelolaan keuangan desa. 


\section{KAJIAN LITERATUR}

\section{Kinerja Pengelolaan Keuangan Desa}

Undang-Undang Nomor 6 Tahun 2014 tentang desa yaitu semua hak dan kewajiban desa yang dapat dinilai yang berhubungan dengan pelaksanaan hak dan kewajiban desa. Hak dan kewajiban tersebut menimbulkan pendapatan, belanja, pembiayaan yang perlu diatur dalam pengelolaan keuangan desa meliputi perencanaan, pelaksanaan, penatausahaan, pelaporan dan pertanggungjawaban. Pengeloalaan keuangan desa termasuk juga dalam mengelola kekayaan, potensi maupun aset yang dimiliki desa. Pengelolaan kekayaan milik desa merupakan rangkaian kegiatan mulai dari perencanaan, pengadaan, penggunaan, pemanfaatan, pengamanan, pemeliharaan, penghapusan, pemindahtanganan, penatausahaan, pelaporan, penilaian, pembinaan, pengawasan, dan pengendalian kekayaan milik desa. Pengelolaan kekayaan milik desa bertujuan untuk meningkatkan kesejahteraan masyarakat desa dan meningkatkan pendapatan desa. Permendagri Nomor 20 Tahun 2018 terkait pengelolaan keuangan desa dilaksanakan dalam masa satu tahun anggaran terhitung mulai 1 Januari sampai dengan 31 Desember.

\section{Kapasitas Aparatur Desa}

Kapasitas aparatur desa adalah semua unsur yang mempunyai peran penting dan terlibat di dalam lingkungan desa. Contohnya seperti BPD, LKMD/LPM, karang taruna, PKK, pemangku adat, RW, RT, kadus, kaur/kasi, sekdes, dan kades. Pemerintah desa merupakan unit terdepan dan berhadapan langsung dengan pelayanan pemerintah dan pemberdayaan masyarakat, serta menjadi tonggak utama untuk keberhasilannya suatu program pemerintah. Sebagai unit penyelenggaraan pemerintah terbawah, maka profesionalisme perangkat desa mutlak dibutuhkan mengigat tugas dan fungsi desa cukup komplek yang antara lain mengatur pemerintah, pembangunan dan masyarakat agar terciptanya kesejahteraan dan potensi masyarakat agar bisa mandiri dan sejahtera.

\section{Ketaatan Pelaporan Keuangan}

Ketaatan pelaporan keuangan oleh aparatur desa berdasar pada Permendagri Nomor 118 Tahun 2014 yang mengatur mengenai asas pengelolaan keuangan desa yang meliputi transparasi, akuntabel, partisipatif, tertib dan disiplin anggaran. Memenuhi prinsip transparasi dan akuntabilitas, maka kepala desa wajib untuk menyusun dan menyampaikan laporan atas pelaksanaan tugas, kewenangan, hak, dan kewajiban dalam pengelolaan keuangan desa. Laporan yang harus disusun yaitu: laporan realisasi pelaksanaan APBDesa dan laporan realisasi penggunaan dana desa.

Laporan APBDesa disampaikan kepala desa kepada bupati/walikota tiap semester tahun berjalan. Untuk laporan pertama disampaikan paling lambat bulan Juli tahun berjalan sedangkan untuk laporan akhir tahun disampaikan paling lambat bulan Januari tahun berikutnya. Laporan realisasi pelaksanaan APBDesa semester pertama berisi tentang realisasi pendapatan, belanja dan pembiayaan untuk seluruh smber dana yang dikelola pemerintah desa selama semester pertama yang dibandingkan dengan target anggarannya. Laporan realisasi pelaksaan APBDesa semester akhir berisi tentang akumulasi realisasi pendapatan, belanja dan pembiayaan sampai dengan akhir tahun anggaran. 
Laporan realisasi penggunaan dana desa disampaikan oleh kepala desa kepada bupai/walikota sebagai persyaratan untuk setiap tahapan (pasal 25 Peraturan Menteri Keuangan Nomor 49/PMK.07/2016) laporan realisasi penggunaan dana desa terdiri atas laporan realisasi penggunaan dana desa tahun anggaran sebelumnya; dan laporan realisasi penggunaan dana desa tahap 1.

\section{Kualitas Pengawasan BPD}

Badan Permusyawaratan Desa/BPD adalah unsur yang berkedudukan sebagai unsur dalam penyelenggara pemerinta desa dalam Peraturan Pemerintah Nomor 72 Tahun 2005 Pasal 29. BPD memiliki kedudukan yang sejajar dengan perangakat desa. BPD mempunyai tugas yaitu membahas dan menyepakati rancangan peraturan desa bersama kepala desa; menampung dan menyalurkan aspirasi masyarakat desa, dan melakukan pengawasan kinerja kepala desa. BPD mempunyai peran penting dalam menciptakan pemerintah yang baik dan diposisikan sebagai penghubung antar kepentingan masyarakat yang mesti diperjuangkan dengan kepentingan pemerintah desa yang harus diawasi. BPD mempunyai peran yang strategis dalam menentukan penyelenggaraan pemerintah desa yang transparan, akuntabel dan bertanggung jawab sehingga tercipta suatu desa yang demokratis.

\section{Hasil-hasil Penelitian Sebelumnya}

Beberapa peneliti terdahulu telah menemukan bukti empiris tentang pengaruh kinerja pengelolaan keuangan desa, dengan hasil penelitian yang beragam. Penelitian yang dilakukan oleh Munti dan Fahlevi (2017) di Kecamatan Gandapura Kabupaten Bireuen Aceh menggunakan metoda sensus/total sampling. Hasil penelitian tersebut menunjukkan bahwa kapasitas aparatur desa, ketaatan pelaporan keuangan, dan kualitas pengawasan badan permusyawaratan desa berpengaruh positif terhadap kinerja pengelolaan keuangan dana desa pada Kecamatan Gandapura di Kabupaten Bireuen.

Adha (2016) meneliti tentang pengaruh pengawasan badan permusyawaratan desa terhadap kinerja kepala desa dalam pembangunan desa Rambah Kabupaten Rokan Hulu. Hasil penelitian Adha (2016) menunjukkan bahwa pengawasan yang dilakukan BPD dalam kategori baik terhadap kinerja kepala desa Rambah. Secara statistik hasil penelitian Adha (2016) ini menunjukkan bahwa pengawasan BPD berpengaruh positif dan signifikan terhadap kinerja kepala desa dalam pembangunan dengan nilai koefisien determinasi sebesar 0,424. Hal ini berarti pengawasan BPD memiliki pengaruh sebesar 42,4\% terhadap kinerja kepala desa.

Asrori (2014) meneliti tentang kapasitas perangkat desa dalam penyelenggaraan pemerintah desa di Kabupaten Kudus. Penelitian ini bersifat deskriptif analisis dengan pendekatan kualitatif pada tiga kecamatan di Kabupaten Kudus, yaitu Kecamatan Dawe, Kecamatan Jekulo, dan Kecamatan Undaan. Penelitian tersebut dilakukan di 26 desa. Hasil penelitian ini menunjukkan bahwa tingkat pemahaman perangkat desa dalam memahami majemen sumber daya manusia maupun kemampuan teknis perangkat desa masih kurang. Mayoritas perangkat desa belum optimal dalam mengikuti pendidikan dan pelatihan/bimbingan teknik kompetensi. 
Paramitha, Domail \& Suwondo (2013) meneliti tentang kinerja aparat pemerintah desa dalam rangka otonomi desa Gulu Kecamatan Maospati Kabupaten Magetan. Hasil penelitian tersebut menunjukkan bahwa semangat kerja aparat Desa Gulun terlihat sangat baik, tingkat penyelesaian tugas kinerja aparat desa baik, dan dalam hal mengambil keputusan pemerintah desa menetapkan RAPBDes serta pemilihan kelembagaan pemerintah desa mengacu pada aturan-aturan yang telah ditaati. Kemudian pelayanan kesehatan masyarakat sudah berjalan dengan baik walaupun sarana dan prasarana kesehatan belum optimal. Pembangunan desa terlihat maju yang menunjukkan bahwa dana desa dialokasikan dengan baik untuk memajuan dan kesejahteraan masyarakat Desa Gulun.

Aristia (2015) meneliti tentang kemampuan aparatur desa dalam pelayanan administrasi kependudukan di Kampung Datah Bilang Baru Kecamatan Long Hubung Kabupaten Mahakam Ulu. Hasil penelitian tersebut menunjukkan bahwa secara umum kemampuan aparatur desa dalam pelayanan administrasi kependudukan belum dapat berjalan secara optimal. Hal ini disebabkan masih kurangnya pemahaman tugas pokok dan fungsi aparatur desa sesuai dengan jabatannya dan tanggung jawabnya masingmasing. Urusan-urusan pemerintahan desa dan pelayanan kepada masyarakat banyak dilakukan oleh Sekretaris Desa.

\section{Rerangka Penelitian dan Pengembangan Hipotesis}

Penelitian ini menggunakan kapasitas aparatur desa, ketaatan pelaporan keuangan, dan kualitas pengawasan BPD sebagai faktor yang memengaruhi kinerja pengelolaan desa. Berdasar penjelasan teori dan hasil-hasil penelitian sebelumnya, maka peneliti menyusun rerangka penelitian sebagai berikut:

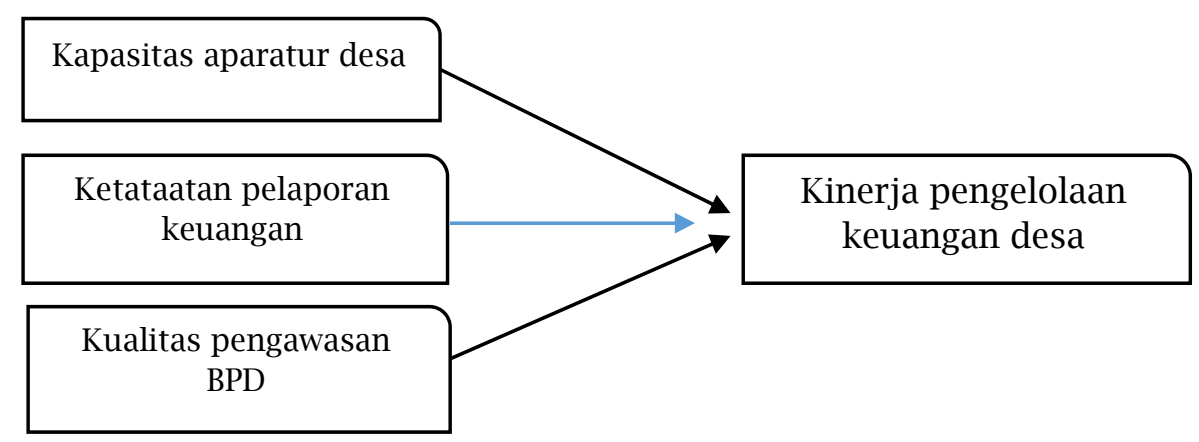

Gambar 1. Rerangka Penelitian

Sumber: Munti dan Fahlevi, 2017

\section{Kapasitas Aparatur Desa terhadap Kinerja Pengelolaan Keuangan Desa}

Islami (2016) dalam Munti dan Fahlevi (2017) menyatakan kapasitas merupakan kemampuan yang dimiliki individu suatu organisasi atau suatu sistem dalam melaksanakan fungsi-fungsinya secara efektif, efisien, dan berkelanjutan sesuai dengan aturan yang berlaku untuk mecapai tujuan bersama dalam pembangunan. Tjiptoherianto et al. (2010) dalam Munti dan Fahlevi (2017) menjelaskan kinerja dan kualitas kapasitas 
sumber daya manusia dalam melaksanakan suatu fungsi, termasuk akuntansi, dapat dilihat dari level of responsibility dan kompetensi sumber daya tersebut. Apabila aparatur desa memiliki tanggung jawab dan kompetensi, maka diharapkan dapat meningkatkan kinerja pengelolaan desa. Aristia (2015) dan Munti dan Fahlevi (2017) menyatakan bahwa kemampuan aparatur desa dalam hal kapasitas sumber daya manusia yaitu pengetahuan sangat menentukan baik buruknya kinerja pengelolaan keuangan desa tersebut. Hal ini sejalan dengan pendapat Asrori (2014) mengemukakan bahwa pencapaian kinerja dipengaruhi oleh kapasitas aparatur desa yang memadai termasuk kemampuan, pengetahuan, pengalaman dan motivasi lingkungan kerja. Berdasarkan paparan tersebut, maka hipotesis yang dirumusan adalah:

$\mathrm{H}_{1}$ : Kapasitas aparatur desa berpengaruh terhadap kinerja pengelolaan keuangan desa

\section{Ketaatan Pelaporan Keuangan terhadap Kinerja Pengelolaan Keuangan Desa}

Permendagri Nomor 113 Tahun 2014 mengatur mengenai asas pengelolaan keuangan desa yang meliputi transparansi, akuntanbel, partisipatif \& tertib, dan disiplin anggaran. Transparansi bermakna bahwa segala akses terhadap informasi dan proses pengambilan keputusan dimiliki oleh masyarakat dengan tujuan untuk memastikan pengelolaan kegiatan diketaui umum. Akuntanbel dalam hal konteks ini didefinisikan sebagai pertanggungjawaban secara moral, teknis, hukum, dan administratif. Pengelolaan keuangan pemerintah harus melibatkan masyarakat secara aktif sejak fase perencanaan sampai dengan pengawasan kegiatan (parsitipasif). Selanjutnya, tertib dan disiplin anggaran yang tercermin dari konsistensi, tepat waktu, tepat jumlah, dan taat asas.

Apabila aparatur desa mentaati asas pengelolaan keuangan desa yang meliputi transparansi, akuntanbel, partisipatif \& tertib, dan disiplin anggaran, maka diharapkan meningkatkan kinerja pengelolaan keuangan desa. Hasil penelitian Munti dan Fahlevi (2017) menunjukkan bahwa implementasi pengelolaan dan penatausahaan keuangan desa berpengaruh terhadap kelancaran administrasi pemerintah desa. Hal ini disebabkan oleh semakin taat aparatur desa dalam membuat pelaporan keuangan desa, maka semakin baik pula kinerja pengelolaan keuagan desa. Berdasarkan paparan tersebut, maka hipotesis yang dirumuskan adalah:

$\mathrm{H}_{2}$ : Ketaatan pelaporan keuangan desa berpengaruh terhadap kinerja pengelolaan keuangan desa.

\section{Kualitas Pengawasan BPD terhadap Kinerja Pengelolaan Keuangan Desa}

Kualitas pengawasan dilakukan dengan cara mendorong atau memotivasi orang yang tepat untuk melakukan kegiatan yang tepat untuk mencapai hasil yang tepat (Balemans, 2013 dalam Munti dan Fahlevi, 2017). Menurut Permendagri Nomor 113 Tahun 2014 menyatakan bahwa BPD adalah institusi yang bertanggung jawab menjalankan fungsi pemerintah yang anggotanya merupakan representasi penduduk desa berdasarkan keterwakilan area yang ditetapkan secara demoktratis. Hal ini dapat diartikan bahwa kinerja pengelolaan keuangan desa umumnya ditentukan oleh bagaimana kualitas 
pengawasan yang dilakukan oleh BPD. Hasil penelitian Munti dan Fahlevi (2017) dan Adha (2016) yang menemukan bahwa pengawasan BPD berpengaruh terhadap kinerja kepala desa. Berdasar penjelasan tersebut, maka hipotesis penelitian dirumuskan:

$\mathrm{H}_{3}$ : Kualitas pengawasan BPD berpengaruh terhadap kinerja pengelolaan keuangan desa.

\section{METODA PENELITIAN}

\section{Objek Penelitian}

Penelitian ini merupakan penelitian kuantitatif berdasar pada pengolahan data primer yang berasal dari tanggapan para responden atas kuesioner penelitian yang berjumlah 39 responden yang ditentukan berdasar purposive sampling dengan kriteria bersedia mengisi kuesioner. Kemudian 2 informan yang bersedia diwawancarai yaitu anggota BPD dan bendahara desa. Responden dan informan penelitian ini terdiri atas aparatur perangkat desa dan tokoh masyarakat yang menjadi anggota BPD di Desa Panggungharjo.

\section{Definisi Operasional dan Pengukuran Variabel}

Variabel dependen dalam penelitian ini adalah kinerja pengelolaan keuangan desa merupakan hasil kerja atau prestasi aparatur desa dalam melaksanakan seluruh kegiatan secara ekonomis, efisiensi, efektivitas dan pelaporan yang memadai meliputi perencanaan, pelaksanaan, pelaporan dan pertanggungjawaban keuangan desa (Permendagri Nomor 113 Tahun 2014 Pasal 1 Ayat 7). Penelitian ini menggunakan instrumen Munti dan Fahlevi (2017) dengan pengukuran menggunakan 5 skala Likert. Artinya semakin tinggi skor yang diperoleh, maka semakin tinggi kinerja pengelolaan keuangan suatu desa.

Variabel independen yang pertama adalah kapasitas aparatur desa merupakan kemampuan individu yang harus dimiliki oleh aparatur desa meliputi permasalahan, keterampilan, dan kemampuan untuk melaksanakan tugas pokok dan fungsinya secara efektif, efisien, dan berkelanjutan (Islami, 2016 dalam Munti dah Fahlevi, 2017). Instrumen variabel ini menggunakan kuesioner yang digunakan oleh peneliti sebelumnya yaitu Munti dan Fahlevi (2017). Kuesioner kapasitas aparatur desa diukur menggunakan 5 skala Likert. Artinya semakin tinggi skor yang diperoleh, maka semakin tinggi kapasitas aparatur suatu desa.

Kedua, ketaatan pelaporan keuangan merupakan kesedian untuk tunduk kepada hukum/aturan yang berlaku dalam melaksanakan tugas dan fungsinya aparatur desa untuk mempertanggungjawabkan laporan keuangan secara transparansi, akuntabel partisipatif dan tertib administrastif dan peraturan (Permendagri Nomor 113 Tahun 2014 Pasal 2 Ayat 1). Instrumen variabel ini mengacu pada kuesioner penelitian Munti dan Fahlevi (2017) yang diukur menggunakan 5 skala Likert. Artinya semakin tinggi skor yang diperoleh, maka semakin tinggi ketaatan pelaporan keuangan suatu desa.

Kapasitas pengawasan BPD merupakan variabel independen penelitian 3 yaitu kegiatan yang dilakukan untuk mengetahui hasil pelaksanaan pekerjaan yang dilakukan aparatur desa, menilai kesesuaian hasil dengan perencanaan dan peraturan (Manullang, 2008:184 dalam Munti dahn Fahlevi, 2017). Instrumen variabel ini mengacu pada 
kuesioner Munti dan Fahlevi (2017) yang diukur r menggunakan 5 skala Likert. Artinya semakin tinggi skor yang diperoleh, maka semakin tinggi pengawasan BPD terhadap suatu desa.

\section{Teknik Analisis Data}

Analisis data penelitian ini menggunakan analisis regresi berganda, dengan persamaan sebagai berikut:

$$
Y=\alpha+\beta_{1} X_{1}+\beta_{2 .} X_{2}+\beta_{3} \cdot X_{3}
$$

Keterangan:

Y : Kinerja Pengelolaan Keuangan Desa

$\alpha \quad$ : Konstanta

$\beta_{1} \ldots \beta_{3}$ : Koefisien Regresi

$\mathrm{X}_{1}$ : Kapasitas Aparatur Desa

$\mathrm{X}_{2}$ : Ketaatan Pelaporan Keuangan

$\mathrm{X}_{3}$ : Kapasitas Pengawas BPD

e : Standard Error

\section{HASIL DAN PEMBAHASAN}

\section{Analisis Deskriptif}

Panggungharjo adalah desa yang terletak di Kecamatan Sewon, Kabupaten Bantul, DIY. Desa Panggungharjo merupakan gabungan dari tiga kelurahan, yakni Cabeyan, Prancak, dan Krapyak. Desa ini dibentuk berdasarkan keputusan Dewan Pemerintah Daerah Yogyakarta Nomor 148/D.pem.D/OP tertanggal 23 September 1947 yang dengan keputusan dewan pemerintah, Hardjo Sumarto, diangkat sebagai lurah desa Panggungharjo yang pertama. Desa Panggungharjo memiliki luas wilayah 560.966.5 Ha yang terdiri dari 14 pedukuhan yang terbagi menjadi 118 RT. Desa Panggungharjo secara langsung berbatasan dengan kawasan perkotaan Yogyakarta, sehingga menyebabkan kawasan ini tumbuh menjadi strategis ekonomi.

Deskripsi responden dalam penelitian ini digunakan untuk mengetahui distribusi responden jika dilihat dari jenis kelamin, lama berkerja, dan jabatan dalam bentuk persentase. Berdasar jenis kelamin, terdapat 59\% responden laki-laki dan $41 \%$ responden perempuan. Berdasarkan masa bekerja diketahui bahwa mayoritas responden dalam penelitian ini memiliki lama bekerja $>5$ tahun, yaitu sebanyak 20 orang $(51,3 \%)$. Sementara itu, responden yang memiliki masa bekerja 1-3 tahun sebanyak 12 orang (30,8\%) dan masa bekerja 4-5 tahun sebanyak 7 orang (17,9\%). Adapun deskripsi sampel penelitian sebanyak 39 responden berdasarkan jabatan disajikan pada Tabel 1. Juga disertai dengan wawancara kepada 2 informan yaitu anggota BPD dan Bendahara. 
Tabel 1. Deskriptif Jabatan

\begin{tabular}{lcc}
\hline \multicolumn{1}{c}{ Keterangan } & Total & Persentase \\
\hline Carik desa & 1 & $2,6 \%$ \\
Dukuh & 13 & $33,3 \%$ \\
Kasi & 3 & $7,7 \%$ \\
Kaur & 3 & $7,7 \%$ \\
Kepala desa & 1 & $2,6 \%$ \\
Staf & 12 & $30,8 \%$ \\
Staf honorer & 6 & $15,4 \%$ \\
& 39 & $\mathbf{1 0 0 \%}$ \\
\hline
\end{tabular}

Sumber: Data primer, diolah (2021)

\section{Uji Kualitas Data}

Berdasar uji kualitas data diketahui keseluruhan item dalam instrumen penelitian dinyatakan valid karena $r$ hitung lebih besar dari r tabel. (0,3160). Demikian pula untuk uji reliabilitas diketahui bahwa pernyataan-pernyataan kuesioner telah memenuhi persyaratan reliabilitas yaitu nilai cronbach alpha $>0,60$.

\section{Analisis Regresi Berganda}

Analisis regresi pada dasarnya adalah studi mengenai ketergantungan variabel dependen dengan satu atu lebih variabel independen dengan tujuan untuk mengestimasi dan/atau memperdiksi rata-rata populasi atau nilai variabel independen yang diketahui (Ghozali, 2016). Sebelum melakukan regresi berganda terdapat syarat yang harus dilalui yaitu melalukan uji asumsi klasik. Model regresi penelitian ini telah memenuhi uji asumsi klasik yang meliputi uji normalitas, multikolinearitas, dan heteroskedastisitas. Hal ini menunjukkan bahwa model regresi penelitian ini layak untuk digunakan sebagai prediktor. Dengan demikian, analisis dapat dilanjutkan ke tahapan pengujian hipotesis yang hasilnya disajikan dalam Tabel 2 berikut ini.

Tabel 2. Hasil Uji Analisis Regresi Berganda

\begin{tabular}{lcccc}
\hline \multicolumn{1}{c}{ Variabel } & Signifikansi & Koefesien & Alpha & Keputusan \\
\hline Kapasitas Aparatur Desa $\left(\mathrm{X}_{1}\right)$ & 0,000 & 0,607 & 0,05 & $\mathrm{H}_{1}$ terdukung \\
Ketaatan Pelaporan Keuangan $\left(\mathrm{X}_{2}\right)$ & 0,032 & 0,313 & 0,05 & $\mathrm{H}_{2}$ terdukung \\
Kapasitas Pengawasan BPD $\left(\mathrm{X}_{3}\right)$ & 0,010 & 0,302 & 0,05 & $\mathrm{H}_{3}$ terdukung \\
\hline
\end{tabular}




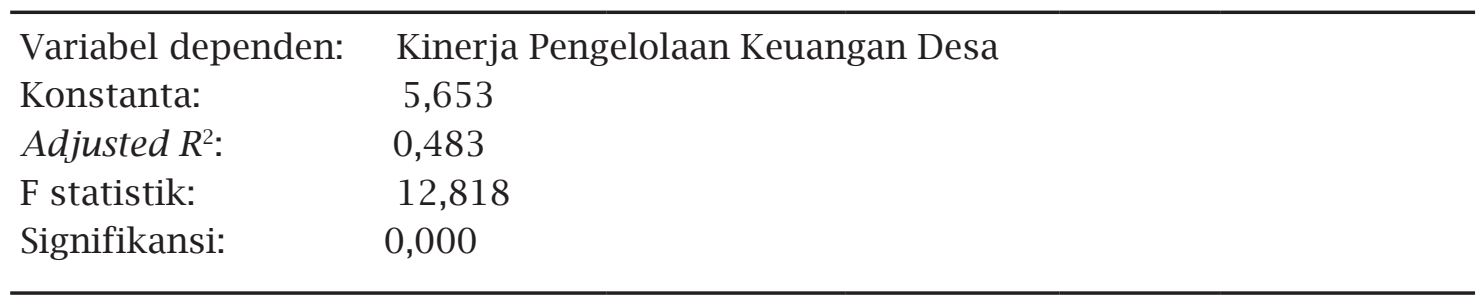

Sumber: Data primer, diolah (2021)

Berdasarkan hasil pengujian pada Tabel 2 dapat dirumuskan persamaan regresi untuk mengetahui pengaruh kapasitas aparatur desa, ketaatan pelaporan keuangan, dan kapasitas pengawasan BPD terhadap kinerja pengelolaan keuangan desa sebagai berikut:

$$
Y=5,683+0,607 X_{1}-0,313 X_{2}+0,302 X_{3}
$$

Nilai koefisien determinasi penelitian ini adalah 0,483. Hal ini berarti 48,3\% kinerja pengelolaan keuangan desa dipengaruhi oleh variabel independen yang digunakan dalam penelitian ini. Sedangkan sisahnya 51,7\% dijelaskan dipengaruhi oleh variabel lain di luar penelitian ini.

Berdasar Tabel 2 diketahui bahwa uji statistik F menunjukkan nilai signifikansi sebesar 0,000 dan angka ini lebih besar dari $\alpha=0,05$ maka dapat dinyatakan bahwa minimal terdapat satu variabel independen yang secara bersama-sama berpengaruh terhadap variabel dependen. Uji variabel (uji t) bertujuan untuk menguji signifikasi pengaruh masing-masing variabel independen terhadap variabel dependen yang diformulasikan dalam model. Berdasarkan hasil pengujian pada Tabel 2 menunjukkan bahwa statistik t antara variabel independen dengan variabel dependen sebagai berikut:

a. Variabel kapasitas aparatur desa memiliki nilai signifikasi sebesar 0,000 dan angka ini lebih kecil dari $\alpha$. Hal ini berarti bahwa $\mathrm{H}_{1}$ terdukung sehingga dapat dikatakan bahwa variabel kapasitas aparatur desa berpengaruh terhadap kinerja pengelolaan keuangan desa.

b. Variabel ketaatan pelaporan keuangan memiliki nilai signifikasi sebesar 0,032 yang lebih kecil dari $\alpha$. Hal ini berarti bahwa $\mathrm{H}_{2}$ terdukung sehingga dapat dikatakan bahwa variabel ketaatan pelaporan keuangan berpengaruh terhadap kinerja pengelolaan keuangan desa.

c. Variabel kapasitas pengawasan BPD memiliki nilai signifikasi sebesar 0,010 dan nilai ini lebih kecil dari $\alpha$. Hal ini berarti bahwa $\mathrm{H}_{3}$ terdukung yang menyatakan bahwa variabel kapasitas pengawasan BPD berpengaruh terhadap kinerja pengelolaan keuangan desa.

\section{PEMBAHASAN}

Hasil pengujian hipotesis pertama pada penelitian ini menunjukkan bahwa kapasitas aparatur desa berpengaruh terhadap kinerja pengelolaan keuangan desa. Hal ini menunjukkan bawa semakin tinggi tingkat kapasitas aparatur desa tentang 
pengelolaan keuangan desa maka akan semakin meningkatkan kinerja pengelolaan keuangan desa. Berdasarkan hasil wawancara menunjukkan bahwa aparatur desa mempertanggungjawabkan kinerja yang dihasilkan mulai dari alur pencairan, penggunaan, dan pelaporan atas penggunaan dana desa. Hal ini menunjukkan pemahaman apartur desa terkait peraturan dana desa, sehingga kapasitas aparatur ini mendukung kinerja pengelolaan dana desa. Hasil penelitian ini konsisten dengan hasil penelitian yang dilakukan oleh Aristia (2015) dan Munti dan Fahlevi (2017) yang menyatakan bahwa kemampuan aparatur desa dalam hal kapasitas sumberdaya manusia yaitu pengetahuan sangat menentukan baik buruknya kinerja pengelolaan desa tersebut.

Berdasar hasil pengujian regresi berganda didapatkan hasil bahwa mendukung hipotesis dua yaitu ketaatan pelaporan keuangan meningkatkan kinerja pengelolaan keuangan desa. Hal ini juga dapat terkonfirmasi dari hasil wawancara yang menunjukkan dana desa yang diperoleh Desa Panggungharjo pada tahun 2020 sebesar Rp1,7M digunakan sesuai dengan program dan kegiatan yang direncanakan yang kemudian dipertanggungjawabkan melalui pelaporan keuangan dan dilakukan secara transparan. Hasil penelitian ini sejalan dengan penelitian yang dilakukan oleh Munti dan Fahlevi (2017) yang menunjukkan bahwa implementasi pengelolaan dan penatausahaan keuangan desa berpengaruh terhadap kinerja pengelolaan keuangan desa.

Berdasarkan hasil pengujian regresi berganda didapatkan hasil yang mendukung hipotesis tiga. Hal ini dapat diartikan bahwa kinerja pengelolaan keuangan desa secara umum juga ditentukan oleh kualitas pengawasan yang dilakukan oleh BPD. Berdasarkan hasil wawancara menunjukkan peran BPD dalam pembangunan desa bahwa BPD berperan aktif dalam penyusunan anggaran, pengawasan pelaksanaan dana desa, hingga memastikan bahwa pelaporan dana desa sampai ke kecamatan dan kabupaten sebelum bulan Maret setelah tahun anggaran berakhir. Pengawasan BPD dalam semester pertama dalam tahun anggaran berjalan dilakukan untuk mengetahui tingkat penyerapan anggaran dana desa serta melakukan evaluasi. Hasil penelitian ini sejalan dengan temuan Adha (2016) dan Munti dan Fahlevi (2017) yang menemukan pengawasan BPD berpengaruh terhadap kinerja pemerintah desa.

\section{SIMPULAN DAN SARAN}

Simpulan dari penelitian ini bahwa kapasitas aparatur desa, ketaatan pelaporan keuangan, dan kualitas pengawasan BPD merupakan faktor yang dapat memengaruhi kinerja pengelolaan keuangan desa. Keterbatasan penelitian ini terletak pada jumlah responden dan informan yang dapat diwawancara dikarenakan terkendala kondisi pandemi yang memiliki konsekuensi pembatasan aktivitas. Peneliti selanjutnya diharapkan dapat memertimbangkan untuk memperluas objek sehingga hasil penelitian lebih dapat digeneralisasi. Selain itu, dapat pula menambahkan variabel lain yang belum digunakan dalam penelitian ini, seperti pemanfaatan teknologi informasi dan komitmen aparatur desa. 


\section{REFERENSI}

Adha, A. H. (2016). Pengaruh Pengawasan Badan Permusyawaratan Desa terhadap Kinerja Kepala Desa dalam Pembangunan Desa Rambah Utama Kecamatan Rambah Samo Kabupaten Rokan Hulu. Jurnal Online Mahasiswa, 3 (2), 36-47.

Aristia, R. (2015). Studi tentang Kemampuan Aparatur Desa dalam Pelayanan Administrasi Kependudukan di Kampung Dtah Bilang Baru Kecamatan Long Hubung Kabupaten Mahakam Ulu. Jurnal Ilmu Pemerintah, 3 (1), 443-457.

Asrori. (2014). Kapasitas Aparatur Desa dalam Penyelenggaraan Pemerintah Desa di Kabupaten Kudus. Jurnal Bina Praja, 6 (2), 73-88.

Buku Pintar Dana Desa. (2017). Buku Pintar Dana Desa. Retrieved from https://www. kemenkeu.go.id/media/6749/buku-pintar-dana-desa.pdf.

Ghozali, I. (2016). Aplikasi Analisis Multivariete dengan Program IBM SPSS23 (Edisi 8). Cetakan ke VIII. Semarang: Badan Penerbit Universitas Diponegoro.

http://www.panggungharjo.desa.id/prestasi/

Munti, F., \& Fahlevi, H. (2017). Determinan Kinerja Pengelolaan Keuangan Desa: Studi pada Kecamatan Gandapura Kabupaten Bireuen Aceh. Jurnal Akuntansi dan Investasi, $18(2), 172-182$.

Paramitha, L. M., \& Suwondo, T. D. (2013). Kinerja Aparat Pemerintah Desa dalam Rangka Otonomi Desa. Jurnal Administrasi Publik, Volume 1, Nomor 4, Hal. 91-100.

Peraturan Pemerintah Republik Indonesia Nomor 43 Tahun 2014 tentang Peraturan Pelaksanaan Undang-Undang Nomor 6 Tahun 2014 tentang Desa.

Peraturan Pemerintah Nomor 72 Tahun 2005 tentang Desa

Permendagri Nomor 113 Tahun 2014 tentang Pengelolaan Keuangan Desa.

Undang-Undang Republik Indonesia Nomor 6 Tahun 2014 tentang Desa. 